\title{
Effect of Pilates Exercise on Primary Dysmenorrhea
}

\author{
EMAN M. EL-BABLY, M.Sc.*; KHADIGA S. ABD EL-AZIZ, Ph.D.*; \\ ASMAA M. EL-BANDRAWY, Ph.D.* and MOHAMAD F. ABO EL-ENEIN, M.D.** \\ The Department of Physical Therapy for Woman's Health, Faculty of Physical Therapy, Cairo University* and \\ The Department of Obstetrics \& Gynecology \& its Surgery, Om El-Masryeen Hospital, Ministry of Health**
}

\begin{abstract}
Background: Primary dysmenorrhea complicates the lives among adolescents females, affects the quality of life of many women in their reproductive years. Pilates exercise is a safe, non invasive treatment modality to relief pain of primary dysmenorrhea.

Aim of Study: To investigate the effect of Pilates exercises on primary dysmenorrhea.

Subjects and Methods: This study was carried out upon 30 girls, theirage ranged between 18-23 years. They diagnosed as having primary dysmenorrhea with regular menstrual cycles. They were selected from students of Faculty of Physical Therapy, Cairo University with body mass index did not exceed $30 \mathrm{~kg} / \mathrm{m}^{2}$. They did not receive any anti-inflammatory or anti-spasmotic drugs during the study. They were randomly assigned into two groups. Control group (A) received TENS (frequency $100 \mathrm{~Hz}$ with pulse width of 95 microseconds) only andthe study group (B) received Pilates exercises in addition to TENS for eight weeks. Assessment of all participants in all groups (A \& B) was carried out through Visual Analogue Scale (VAS) and plasma cortisol level before and after treatment.
\end{abstract}

Results: The results revealed a significant decrease in intensity of pain and plasma cortisol levelfor both groups (A and B) after the treatment program (study group, $p<0.001 \&$ 0.001 and control group, $p=0.033 \& 0.036$ ) respectively but in favor of group A. There was a positive correlation between intensity of pain andthe plasma cortisol levelofpretreatment values where the $r$-value equals $(+0.571)$ with associated probability value of $(0.001)$.

Conclusion: Pilates exercises are effective, safe and non invasive therapeutic modality in reducing menstrual pain.

Key Words: Primary dysmenorrhea - Pilates exercise - TENS - Visual analogue scale - Plasma cortisol level.

Correspondence to: Dr. Eman M. El-Bably, The Department of Physical Therapy for Woman's Health, Faculty of Physical Therapy, Cairo University

\section{Introduction}

DYSMENORRHEA, also known as painful periods, or menstrual cramps, is pain during menstruation [1]. There are two forms of dysmenorrhea. Primary dysmenorrhea describes pain during the menstrual period without any underlying cause. The onset of pain is usually a few hours before blood flow starts and will last for the first one to two days of the period. Often primary dysmenorrhea becomes less with age or after childbirth. In other way, secondary dysmenorrhea relates to pain during menstrual periods with an underlying pathology. Symptoms will only start after the underlying cause has developed [2].

The major cause of primary dysmenorrhea is still not clear. It is said that prostaglandin and oxytocin hormone initiate uterine muscle contraction which reduces the blood supply to the uterus [3]. Involvement of vasopressin in pathogenesis of primary dysmenorrhea is still controversial [4].

Primary dysmenorrhea derives from hypersensitivity of the adrenergic and cholinergic nerves supplying the uterus that modify rather than initiate contraction. There is short demyelinated adrenergic nerves are found within the uterine wall [5]. Primary dysmenorrhea occur almost exclusively in ovulatory cycles and steroid hormones affect both uterine prostaglandin concentration and myometrium contractility [6]

Physical activities and exercise are widely accepted as a mean of moderating stress and stress related symptoms. Exercise is known to cause the release of endorphins hormones in brain that raise the pain threshold and is shown to improve mood of exercising subjects [7]. 
Pilates exercises belong to a group of so-called body-mind exercises, where the focus is on controlled movement, posture, and breathing. Pilates improves mental and physical well-being, increases flexibility, and strengthens muscles through controlled movements done as mat exercises and strengthen the body [8]

Pilates exercise has a positive effect on health physical fitness as it increases the muscular strength, muscular endurance, flexibility, cardio respiratory endurance and a positive effect on female sex hormone. Pilates exercise is a good one for the promotion of physical metabolism and physiological function by positive change of immunoglobulin and sex hormone [9].

TENS relieves primary dysmenorrhea through two possible mechanisms, the gate control theory and endorphin mediated pain relief. According to the gate control theory, by stimulating largediameter, (A) sensory nerve fibers in a dermatomal segment, a blockage or gating effect is established at the dorsal horn level of the spinal cord inhibiting the transmission of pain related impulses. TENS also induces release of endorphin from these nerve cells and thereby contributes additionally to the relief of pain [10]. The aim of this study was to investigate the effect of Pilates exercises on primary dysmenorrhea.

Hypothesis: Pilates exercises will not be effective in treating primary dysmenorrhea.

\section{Subjects and Methods}

Subjects: 30 volunteer female (age: $18-23$ years, BMI: Did not exceed $30 \mathrm{~kg} / \mathrm{m}^{2}$ ) diagnosed as havingprimary dysmenorrhea were contacted for this study. They all had regular menstrual cycles. They were selected randomly from students of Faculty of Physical Therapy, Cairo University from December 2017 to May 2018. All females who received medications that may affect the results of the study or performing other types of physical activity or having child, smoking, cardiovascular problems or pulmonary problems or suggestive criteria of endometriosis or other gynecological disorders or having any contraindication to TENS were excluded from the study. Patient randomization was reported by physical therapistwho did not belong to the study. Reported patients were randomly assigned into either control group (A) or the study group (B) by using the computer generated random numbers. Allocation was concealed in sequentially numbered opaque envelopes. An independent person who was blindedto the research protocol involved in the trial operated the random assignment. All patients were givenfull explanation of the treatment protocol, and signed informed consents were obtained before participation. This study was approved by the Ethics Committee for Scientific Research of the Faculty of Physical Therapy, Cairo University. Abdominal ultrasonography was done for all participants to exclude any pelvic pathology. All of them were advised not to receive any anti-inflammatory or anti-spasmodic drugs duringthe time of the study.

Participants were randomly assigned into two equal groups (A \& B). Control group (A) received TENS and the study group (B) received Pilates exercises training program in addition to TENS.

All participants in both groups (A \& B) received TENS applicationfrom side lying position. Two electrodewere placed upon the lumbosacral nerve roots and the other two electrodes were placed upon suprapubic region on the anterior aspect of the abdomen. TENS unit was used to deliver standardized TENS stimulation parameters (high frequency $100 \mathrm{~Hz}$ with pulse width of 95 microseconds). The intensitywas gradually increased till tingling sensation without muscle contraction. The stimulation was administered for 30 minutes once per day during the first three days of menstrual cycle. The procedure was repeated on the second consecutive menstrual cycle.

All participants in group (B) participated in Pilates exercise training program. They watched videos about Pilates exercises before treatment to better understand values of Pilates exercises to gain their confidence and cooperation through the study and how to correctly practice them. Then, Pilates exercise program in the form of: Pilates curl, roll-up, rolling like a ball, single straight leg stretch, double leg stretch, teaser 1, Pilates pushups, shoulder bridge, single leg kick was done by every participant in group (A). The exercise program was repeated twice a week for 8 weeks. Each girl was advised not to perform Pilates exercise during menstruation.

Assessment was performed by visual analogue scale and plasma cortisol level at the morning (at 8 clock) on first day of menstruation for all participants in both groups (A \& B) beforeand after treatment.

\section{Results}

Statistical analysis was conducted using SPSS for windows, Version 22 (SPSS, INC., Chi Cago, IL). 
Test of normality for all variables showed that the data was normally distributed so parametric measures were used for the purpose of data analysis.

I- Physical characteristics for both groups $(A \&$ $B)$ : The demographic characteristics of both groups (A \& B) at baseline (age and BMI) revealed no significant differences between the two groups before treatment (Table 1).

Table (1): Demographic data for both groups (A \& B) before treatment.

\begin{tabular}{|c|c|c|c|c|c|c|}
\hline \multirow{2}{*}{ Variables } & \multirow{2}{*}{ Groups } & \multirow{2}{*}{ Mean } & \multirow{2}{*}{ SD } & \multicolumn{2}{|c|}{ Comparison } & \multirow{2}{*}{ S } \\
\hline & & & & \multicolumn{2}{|c|}{$t$-value $p$-value } & \\
\hline \multirow{2}{*}{$\begin{array}{c}\cdot \text { Age } \\
\text { (yrs) }\end{array}$} & Group (A) & 20.20 & \pm 1.474 & \multirow[t]{2}{*}{0.374} & \multirow[t]{2}{*}{0.711} & \multirow[t]{2}{*}{ NS } \\
\hline & Group (B) & 20.40 & \pm 1.454 & & & \\
\hline \multirow{2}{*}{$\begin{array}{c}\text { - Height } \\
(\mathrm{Cm})\end{array}$} & Group (A) & 159.6 & \pm 2.473 & \multirow[t]{2}{*}{0.631} & \multirow[t]{2}{*}{0.533} & \multirow[t]{2}{*}{ NS } \\
\hline & Group (B) & 159 & \pm 2.726 & & & \\
\hline \multirow{2}{*}{$\begin{array}{c}\text { - Weight } \\
(\mathrm{kgs})\end{array}$} & Group (A) & 66.73 & \pm 6.375 & \multirow[t]{2}{*}{1.323} & \multirow[t]{2}{*}{0.197} & \multirow[t]{2}{*}{ NS } \\
\hline & Group (B) & 63.87 & \pm 5.462 & & & \\
\hline \multirow{2}{*}{$\begin{array}{l}\cdot \text { BMI } \\
(\mathrm{kg} / \mathrm{m} 2)\end{array}$} & Group (A) & 26.08 & \pm 2.128 & \multirow[t]{2}{*}{1.079} & \multirow[t]{2}{*}{0.290} & \multirow[t]{2}{*}{ NS } \\
\hline & Group (B) & 25.24 & \pm 2.132 & & & \\
\hline
\end{tabular}

\section{II- Intensity of pain:}

A- Within groups:

Group (A): There was a significant decrease in intensity of pain as revealed by the paired $t$-test between pre and post-treatment in patients of group (A). The mean value of pre-treatment pain intensity using VAS was $(7.33 \pm 1.345)$ and $(6.13 \pm 1.457)$ for post-treatment where the $t$-value was (2.358) and $p$-value was (0.033). The percentage of improvement was $16.37 \%$ (Table 2).

Table (2): Mean of pain intensity pre and post-treatment for group (A).

\begin{tabular}{|c|c|c|}
\hline \multirow{2}{*}{ Group A } & \multicolumn{2}{|c|}{ Intensity of pain } \\
\hline & Pre-treatment & Post-treatment \\
\hline $\begin{array}{l}\text { Mean } \\
\pm \mathrm{SD}\end{array}$ & $\begin{array}{l}7.33 \\
\pm 1.345\end{array}$ & $\begin{array}{l}6.13 \\
\pm 1.457\end{array}$ \\
\hline Mean difference & \multicolumn{2}{|l|}{1.2} \\
\hline Percentage of improvement & \multicolumn{2}{|c|}{$16.37 \% \downarrow$} \\
\hline DF & \multicolumn{2}{|l|}{14} \\
\hline$t$-value & \multicolumn{2}{|c|}{2.358} \\
\hline$p$-value & \multicolumn{2}{|c|}{0.033} \\
\hline$S$ & \multicolumn{2}{|l|}{$\mathrm{S}$} \\
\hline 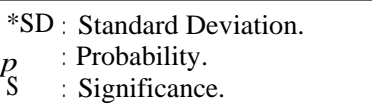 & \multicolumn{2}{|c|}{$\begin{array}{l}S: \text { : Significant. } \\
\text { DF : Degree of Freedom. }\end{array}$} \\
\hline
\end{tabular}

Group $(B)$ : There was a significant decrease in intensity of pain as revealed by the paired $t$-test between pre and post-treatment for patients of group (B). The mean value of pre-treatment pain intensity using VAS was (7.40 \pm 1.404$)$ and $(4.20 \pm$ $1.740)$ for post-treatment, where the $t$-value was (5.779) and $p$-value was (0.001). The percentage of improvement was $40.43 \%$ (Table 3 ).

Table (3): Mean of pain intensity pre and post-treatment for group (B).

\begin{tabular}{lcc}
\hline \multirow{2}{*}{ Group B } & \multicolumn{2}{c}{ Intensity of pain } \\
\cline { 2 - 3 } & Pre-treatment & Post-treatment \\
\hline Mean & 7.40 & 4.20 \\
\pm SD & \pm 1.404 & \pm 1.740 \\
Mean difference & 3.2 \\
Percentage of improvement & $43.24 \% \downarrow$ \\
DF & 14 \\
$t$-value & 5.779 \\
$p$-value & 0.001 \\
$S$ & HS \\
\hline$*$ SD : Standard Deviation. & S : Significant. \\
$p \quad:$ Probability. & DF : Degree of Freedom. \\
\hline
\end{tabular}

\section{B- Between groups:}

There was no significant difference in intensity of pain in pre-treatment values between both groups (A and $\mathrm{B}$ ) where the $t$-value was (0.133) and $p$ value was $(0.895)$, while there was a significant difference in the post-treatment values where the $t$-value was (3.299) and $p$-value was (0.003) with more decrease in group (B) (Table 4).

Table (4): Independent $t$-test for intensity of painbetween both groups (A and $\mathrm{B})$ pre and post-treatment.

\begin{tabular}{|c|c|c|c|}
\hline \multirow{2}{*}{\multicolumn{2}{|c|}{ Independent $t$-test }} & \multicolumn{2}{|c|}{ Intensity of pain } \\
\hline & & Pre & Post \\
\hline & Mean difference & 0.07 & 1.93 \\
\hline & $t$-value & 0.133 & 3.299 \\
\hline & $p$-value & 0.895 & 0.003 \\
\hline & $\mathrm{S}$ & NS & $\mathrm{HS}$ \\
\hline${ }^{* \mathrm{SD}}$ & $\begin{array}{l}\text { : Standard Deviation. } \\
\text { : Probability. } \\
\text { : Significance. }\end{array}$ & \multicolumn{2}{|c|}{$\begin{array}{l}\text { NS : Non-Significant. } \\
S \text { : Significant. }\end{array}$} \\
\hline
\end{tabular}

\section{III-Blood cortisol level:}

\section{A- Within groups:}

$\operatorname{Group}(A)$ : There was a significant decrease in plasma cortisol level as revealed by the paired $t$ test between pre and post-treatment in patients of group (A). The mean value of pre-treatment was $(18.37 \pm 1.481)$ and $(17.93 \pm 1.622)$ for post-treatment where the $t$-value was $(2.318)$ and $p$-value was (0.036). The percentage of improvement was $2.39 \%$ (Table 5).

Group (B): There was a highly significant decrease in plasma cortisol level as revealed by the paired $t$-test between pre and post-treatment in patients of group (B). The mean value of pre- 
treatment was $(18.34 \pm 1.556)$ and $(16.74 \pm 1.508)$ for post-treatment where the $t$-value was (5.04) and $p$-value was (0.001). The percentage of improvement was $8.72 \%$ (Table 6).

Table (5): Mean and \pm SD of plasma cortisol level pre and post-treatment for group (A).

\begin{tabular}{lcc}
\hline \multirow{2}{*}{ Group A } & \multicolumn{2}{c}{ Plasma cortisol level } \\
\cline { 2 - 3 } & Pre-treatment & Post-treatment \\
\hline Mean & 18.37 & 17.93 \\
$\pm \mathrm{SD}$ & \pm 1.481 & \pm 1.622 \\
Mean difference & 0.44 \\
Percentage of improvement & $2.39 \% \downarrow$ \\
DF & 14 \\
$t$-value & 2.318 \\
$p$-value & 0.036 \\
$\mathrm{~S}$ & \multicolumn{2}{c}{$\mathrm{S}$} \\
\hline$*$ SD : Standard Deviation. & $\mathrm{S}:$ Significant. \\
$p$ & DF : Probability. &
\end{tabular}

Table (6): Mean of plasma cortisol level pre and post-treatment for group (B).

\begin{tabular}{|c|c|c|}
\hline \multirow{2}{*}{ Group B } & \multicolumn{2}{|c|}{ Plasma cortisol level } \\
\hline & Pre-treatment & Post-treatment \\
\hline $\begin{array}{l}\text { Mean } \\
\pm \text { SD }\end{array}$ & $\begin{array}{l}18.34 \\
\pm 1.556\end{array}$ & $\begin{array}{l}16.74 \\
\pm 1.508\end{array}$ \\
\hline Mean difference & \multicolumn{2}{|c|}{1.6} \\
\hline Percentage of improvement & \multicolumn{2}{|c|}{$8.72 \% \downarrow$} \\
\hline $\mathrm{DF}$ & \multicolumn{2}{|c|}{14} \\
\hline$t$-value & \multicolumn{2}{|c|}{5.04} \\
\hline$p$-value & \multicolumn{2}{|c|}{0.001} \\
\hline $\mathrm{S}$ & \multicolumn{2}{|c|}{ HS } \\
\hline $\begin{array}{l}* \text { SD : Standard Deviation. } \\
p \quad \text { : Probability. }\end{array}$ & \multirow{2}{*}{\multicolumn{2}{|c|}{$\begin{array}{l}S \quad \text { : Significant. } \\
\text { DF : Degree of Freedom. }\end{array}$}} \\
\hline S : Significance. & & \\
\hline
\end{tabular}

\section{B- Between groups:}

There was no significant difference in intensity of pain in pre-treatment values between both groups (A and $\mathrm{B}$ ) where the $t$-value was $(0.06)$ and $p$-value was (0.953), while there was a significant difference in the post-treatment values where the $t$-value was (2.057) and $p$-value was (0.047) with more decrease in group (B) (Table 7).

Table (7): Independent $t$-test of plasma cortisol level between both groups (A \& B) before and after-treatment.

\begin{tabular}{|c|c|c|c|}
\hline & \multirow{2}{*}{ Independent $t$-test } & \multicolumn{2}{|c|}{ Plasma cortisol level } \\
\hline & & Pre & Post \\
\hline & Mean difference & 0.03 & 1.19 \\
\hline & $t$-value & 0.06 & 2.057 \\
\hline & $p$-value & 0.953 & 0.047 \\
\hline & S & NS & $\mathrm{S}$ \\
\hline $\begin{array}{l}* \mathrm{SD} \\
p \\
\mathrm{~S}\end{array}$ & $\begin{array}{l}\text { : Standard Deviation. } \\
\text { : Probability. } \\
\text { : Significance. }\end{array}$ & \multicolumn{2}{|c|}{$\begin{array}{l}\text { NS : Non-Significant. } \\
\mathrm{S} \text { : Significant. }\end{array}$} \\
\hline
\end{tabular}

\section{IV- Correlation between intensity of pain and the degree of Plasma cortisol level:}

There was a positive correlation between intensity of pain andthe plasma cortisol level forpretreatment values where the $r$-value equals $(+0.54)$ and had an associated probability value of $(0.002)$ (Table 8).

Table (8): Correlation between intensity of pain and the plasma cortisol level.

\begin{tabular}{cl}
\hline \multicolumn{2}{c}{ Correlation coefficient } \\
\hline$t$-value & +0.54 \\
$p$-value & $0.002^{*}$ \\
$\mathrm{~S}$ & $\mathrm{~S}$ \\
\hline$r$-value: Correlation coefficient. & $\mathrm{S}$ : Significance. \\
$p$-value: Probability. & $*$ Significant.
\end{tabular}

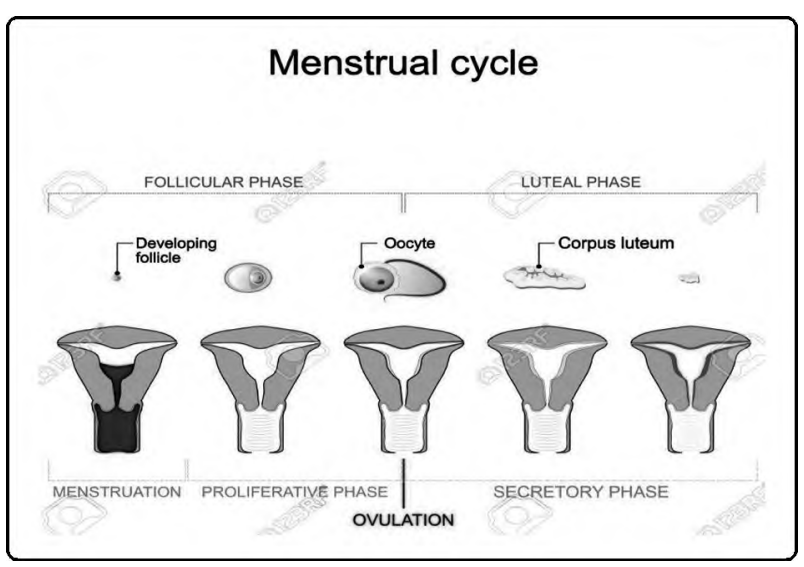

Fig. (1): The ovarian cycle. Quated by

\section{Discussion}

Primary dysmenorrhea is a common gynecological disorder among young women. Its incidence is $40-50 \%$, with severe forms giving rise to $15 \%$ work or school absenteeism and mild forms requiring no medication or analgesics in about $30 \%$. Sixty percent of womenhave severe or moderate pain, $51 \%$ reported limitation of activities, and $17 \%$ reported absenteeism [11]. So, this study was carried out to determinethe effect of Pilates exercises on primary dysmenorrhea.

The results of this study revealed that:

This study revealed significant decrease in intensity of pain and blood cortisol level in control group (A), theseare in line with Parsa and Bashirian [12] who proved that TENS can reduce the intensity of pain associated with primary dysmenorrhea. TENSwas applied for 20 minutes with a frequency of 0-100HZ and 90-100 pulse/seconds forsixtyfour females. They proved that TENS was a safe, effective, on medication method for managing primary dysmenorrhea. 
Also, Michelle et al., [13] concluded that, high frequency TENS was found to be effective for the treatment of dysmenorrhea. It includes the sending of an electric current by placing electrodes on the skin to stimulate the nerves and reduce pain. TENS is thought to alter the body's ability to receive and understand pain signals rather than by having a direct effect on the uterine contractions.

Ibrahim et al., [14] added that transcutaneous electrical nerve stimulation is valuable in improving chronic pancreatitis pain as evidenced by the highly significant decreases in serum cortisol level and nalbuphine intake.

The results of this study is contradicted with Akinbo et al., [15] who concluded that high frequency TENS significantly reduced the pain levels in dysmenorrhoeic women without significantly affecting serum level of cortisol.

The results of this study revealed that, there was a significant decrease in the intensity of pain and plasma cortisol level in study group (B) who was treated by Pilates exercises in addition to TENS. These results were in line with Oswal et al., [16] who concluded that 8 weeks of pilates exercises training can be effective treatment for relieving pain and improving quality of life in females with primary dysmenorrhea.

Dawood, [11] added that therapeutic exercise can increase the secretion of endorphins from the brain and raisethe pain threshold of the body.

Functional menstrual disorders as dysmenorrhea were associated with an increase in cortisol level. It returned nearly to its normal values after exercise [17]. There was a significant association between stress and dysmenorrhea [18]. Emotional distress affects the perceived severity of menstrual pain and disability [19].

Movements of Pilates exercises are linked to concentration of the mind and respiration; when performed smoothly but precisely, it leads to paving new, more ergonomic movement behaviours as well as it provides measurable psychological advantages by reducing stress level [20]

Also, Mastrangelo et al., [1] concluded that the role of physical training has been regarded as a means to reduce stress and biochemical changes in body immune system. One possible mechanism explaining the positive effect of physical activity on intensity of primary dysmenorrhea is associated with stress. Exercise reduces moderate stress and for that the sympathetic activity may be decreased, so the intensity of menstrual pain and other related symptoms may be reduced as well [22]

The results of this study was contradicted with Blakey et al., [23] who did not find any relation between intensity of primary dysmenorrhea pain and physical activity. Also, Ligia et al., [24] found that Pilates method did not improve functionality and pain in patients who have low back pain when compared with control and lumbar stabilization exercise groups.

\section{Conclusion:}

Pilates exercises are effective, safe and non invasive therapeutic modality in reducing menstrual pain.

\section{References}

1- OSAYANDE A.S. and MEHULIC S.: "Diagnosis and initial management of dysmenorrhea", American family physician, 89 (5): 341-6, 2014.

2- LATTHE P. LATTHE M., SAY L., et al.: WHO systematic review of prevalence of chronic pelvic pain: A neglected reproductive health morbidity. BMC Public Health, 6: 177, 2006.

3- TAMRAKAR A.: Textbook of Gynaecology for nurse. 1stedition. NewDelhi: Jaypee Brother Medical Publisher (P) LTD; 13, 2014.

4- VALENTINE L., SLADKEVICIUS P., KINDAHI H., BROEDERS A., MARSAL K. and MELIN P.: "Effects of a vasopressin antagonist in women with dysmenorrhea", Gynecol. Obstet. Invest., 50: 170-7, 2000.

5- WEISSMAN A., HARTZ A., HANSEN M. and JOHNSON S.: "The natural history of primary dysmenorrhea: "A Longitudinal study, BR. J. Obstet. Gynaecol., 111 (4): 345-52, 2004

6- LUMSDEN M. and GAVIGAN J.: "Mensturation and Menstrual Disorder ", In Shaw, R. soutter, W. and stanton. (eds.): "Gynaecology" Churchill living Stone, London, PP.: 465-6 \& 469-73, ${ }^{\mathrm{rd}}$ Ed, 2003.

7- MAHVASH N., EIDY A., MEHDI K., ZAHRA M., MANI M. and SHAHLA H.: "The effect of physical activity on primary dysmenorrhea of female university students", World Applied Sciences Journal, 17 (10): 1246-52, 2012.

8- SYLWIA METEL and AGATA MILERT: Joseph pilates,methodand possibilities of its application in physiotherapy, 11 (2): 19-28, 2007.

9- CHAN NA1, DONGHEE KIM, HAYAN and LEEL M.: "Effect of the pilates exercise on the Health Physical fitness, Immunoglobulin and sex hormone in female Collegen Students", FASEB J., 6 (24): 18-25, 2010.

10- EL-MINAWI A. and HOWARD F.: Dysmenorrhoea, In howard F., Perry P., Carter J., ElMinawi A. and Zeng R. Pelvic pain Diagnosis and Mangement. Textbook, 1 st Ed A Wolters Kluwer company, Philadelphia, New York, london, P. 100-7, 2000.

11- DAWOOD M.Y.: Primary dysmenorrhoea: Advances in pathogenesis and management. J. Obstet. Gynecol., 108: 428-41, 2006. 
12- PARSA P. and BASHIRIAN S.: Effect of Transcutaneous electrical nerve stimulation (TENS) on primary dysmenorrhoea in adolescent girls. J. Postgrad. Med. Inst., 27 (3): 326-30, 2013.

13- MICHELLE PROCTOR, CINDY FARQUHAR, WILL STONES, LIN HE, XIAOSHU and JULIE BROWN: Transcutaneous electrical nerve stimulation for primary dysmenorrhea. Cochrane Gynaecology and fertility Group, 62, 2002.

14- IBRAHIM MOHAMED IBRAHIM ZOHEIRY, MUSTAFA ABDUL-AZIZ MUSTAFA and MAGDYMOSTAFA AHMED: Transcutaneous Electrical Nerve Stimulation Efficacy on Chronic Pancreatitis Pain. Bull. Fac. Ph.Th. Cairo Univ., 17 (2): 9-14, 2012.

15- AKINBO S.R.A., Ph.D., P.T.; TELLA B.A., OLISAH A.J., AJAYI G.O., ALAMU D. and OSHUNDIYA B.: Effect of Transcutaneous Electric Nerve Stimulation (TENS) on Hormones Profile in subjects with primary Dysmenorrhoea-APreliminary study. SA. Journal of Physiotherapy, 63 (3): p. 45, 2017.

16- OSWAL N., SUTAR A. and GHODEY S.: Effect of pilates on pain and quality of life in females with primary dysmenorrhea. In. J. of Allied Med. Sci. and Clin. Res., 5 (2): 473-9, 2017.

17- LOUCKS A. and REDMAN L.: "The effect of stress on menstrual function". J. of trends in endocrinology and metabolism, 15 (10): 466-71, 2004.

18- WANG L., WANG X., WANG W., CHEN C., RONNEN-
NBERG A., GUANG W., HUANG A., FANG Z., ZANG T. and XU X.: "Stress and Dysmenorrhea". A population based prospective study, Occup. Envir. Med. J., 61 (12): 1021-6, 2004

19- METHENY W. and SMITH R.: "The relationship among exercise, stress, and primary dysmenorrhea", Journal of Behavioral Medicine, 12 (6): pp. 569-86, 1989.

20- CREWS L.: Plates: Philosophy and biomechanics. American fitness, Mayto June: 58-62.2, 2006.

21- MASTRANGELO M., GALANTINO M. and HOUSE L.: "Effects of yoga onquality of life and flexibility in menopausal women": A case series. Explore (NY), 3 (1): 42-5, 2007.

22- MAHVASH N., EIDY A., MEHDI K., ZAHRA M., MANI M. and SHAHLA H.: "The effect of physical activity on primary dysmenorrhea offemale university students". World Applied sciences Journal, 17 (10): 1246-52, 2012

23- BLAKEY H., CHISHOLM C., DEAR F., HARRIS B., HARTWELL R., DALEY A. and JOLLY K.: "Is exercise associated with primary dysmenorrhea inYoung women" BJOG: An International Journal of Obstetrics and Gynecology, 177: 222-4, 2010.

24- LIGIA M. PEREIRA, KAREN OBARA, JOSILAINNE M. DIAS, MENACHO and DEBORA A. GUARIGLIA: Comparing the Pilates method with no exercise orlumbar stabilization for pain and functionality in patients with chronic lowback pain: Systematic review and meta analysis. Clinical Rehabilitation, 26 (1): 10-20, 2012.

\section{تآثير تمرينات البيلاتس على عسر الطمث الآولى}

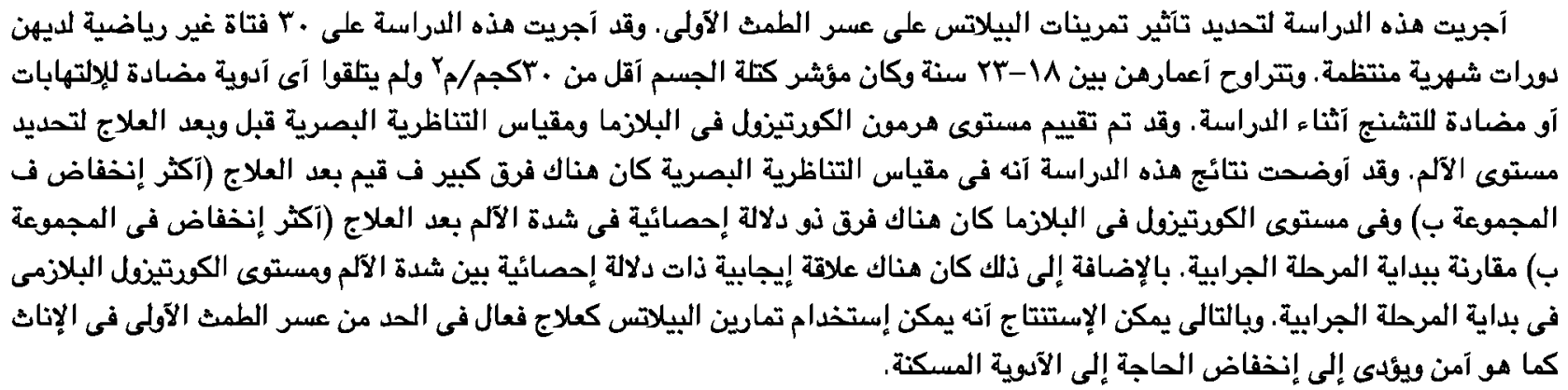

